\title{
PENINGKATAN KEMAMPUAN MENULIS KARANGAN NARASI MELALUI PENERAPAN PEMBELAJARAN COOPERATIVE INTEGRATED READING AND COMPETITION (CIRC) PADA SISWA KELAS IV SD INPRES PANGGENTUNGAN SELATAN KECAMATAN SOMBA OPU KABUPATEN GOWA.
}

\author{
Tasrif Akib \\ Pendidikan Guru Sekolah Dasar, Universitas Muhammadiyah Makassar \\ tasrifakib@unismuh.ac.id
}

\begin{abstract}
Abstrak
Penelitian ini merupakan penelitian tindakan kelas (Class room action research) yang bertujuan untuk tujuan penelitian ini adalah untuk meningkatkan kemampuan menulis karangan narasi melalui penerapan pembelajaran Cooperative Integrated Reading and Competition (CIRC) Pada Siswa Kelas IV SD Inpres Panggentungan Selatan Kecamatan Somba Opu Kabupaten Gowa. Dengan jumlah siswa 35 orang. Teknik Pengumpulan data yang dilakukan dalam penelitian ini adalah: (a) hasil belajar Bahasa Indonesia siswa dikumpulkan dengan memberikan tes menulis narasi pada setiap akhir siklus, (b) data tentang proses belajar mengajar dikumpulkan dengan menggunakan lembar observasi. Data yang telah terkumpul dianalisis secara kuantitatif dan kualitatif. Hasil analisis menunjukkan adanya peningkatan hasil belajar secara kuantitatif ditandai dengan meningkatnya skor rata-rata siswa yaitu dari 69,28 menjadi 76,71 dari skor ideal 100 . Secara kualitatif, terjadi peningkatan kualitas proses belajar yaitu perubahan sikap siswa yang ditandai dengan: (a) Meningkatnya frekuensi kehadiran siswa, (b) Keaktifan siswa dalam proses belajar mengajar, (c) Semakin banyaknya siswa yang memperhatikan penjelasan guru, (d) Semakin banyaknya siswa yang mengajukan pertanyaan dan menjawab tugas dengan benar, (e) Semakin berkurangnya siswa yang meminta bimbingan dan meminta dijelaskan tentang suatu konsep. Dengan demikian dapat disimpulkan bahwa penerapan pembelajaran Cooperative Integrated Reading and Competition (CIRC) dapat meningkatkan kemampuan menulis narasi siswa kelas IV SD Inpres Panggentungan Selatan Kecamatan Somba Opu Kabupaten Gowa.
\end{abstract}

Kata Kunci: Karangan, Narasi, Kooperatif dan CIRC

Abstract

This research was class room action research. The aimed of the study to improve the ability to write the essay narrative through the application of learning Cooperative Integrated Reading Competition (CIRC) Students of Class IV Elementary Instruction Panggentungan Southern District of Somba Opu Gowa with the number of students 35 people. Data collection techniques used in this research are: (a) the results of Indonesian students study were collected by delivering narrative writing test at the end of each cycle, (b) data on the learning process collected using observation sheet. The collected data were analyzed quantitatively and qualitatively. The analysis showed an increase learning outcomes quantitatively characterized by increasing the average score of students, namely from 69.28 into 76.71 of the ideal score of 100. In qualitative terms, an increase in the quality of the learning process that changes the attitude of the students are characterized by: (a) Increased frequency of attendance of students, (b) active participation by students in the learning process, (c) the number of students who pay 
attention to the teacher's explanation, (d) Increasing number of students asking questions and answering the task correctly, (e) the decreasing of students who ask for guidance and ask about a concept explained. It can be concluded that the application of learning Cooperative Integrated Reading Competition (CIRC) can improve students' ability to write narrative fourth grade Inpres South Panggentungan Gowa District of Somba Opu.

\section{Keywords: Authorship, Narrative, Cooperative and CIRC}

\section{PENDAHULUAN}

Beberapa penelitian yang mengungkapkan bahwa kemampuan siswa menulis masih rendah, mulai dari Sekolah Dasar - Peguruan Tinggi, disebabkan karena berbagai faktor. Basri, (2005: 1-2) mengemukakan faktor tersebut antara lain: (1) pokok bahasan menulis tidak memperoleh perhatian serius dari guru dan motivasi siswa dalam menulis sangat minim dan (2) sarana dan metode/strategi pembelajaran menulis belum efektif. Hal tersebut mengisyaratkan bahwa dibutuhkan pembenahan dalam pengajaran menulis.

Studi pustaka peneliti mengungkapkan bahwa yang pernah melakukan penelitian sebelumnya tentang menulis narasi adalah Sawi,(2009) dengan judul penelitian Pemanfaatan Strategi Neighboardhood Walk 'Pengamatan terhadap Lingkungan Sekitar dalam Pembelajaran Menulis Narasi Siswa Kelas X6 SMA Negeri 1 Takalar. Hasil penelitian Sawi menunjukkan bahwa terjadi peningkatan dalam penulisan narasi siswa dengan menggunakan strategi Neighboardhood walk. Selain itu, Nuralim (2011) juga pernah melakukan penelitian dengan judul Upaya peningkatan keterampilan membaca Bahasa Indonesia melalui penerapan model pembelajaran CIRC pada siswa kelas V SDN 240 Walempeng Kabupaten Soppeng. Hasil penelitian tersebut menunjukkan terjadinya peningkatan keterampilan membaca bahasa Indonesia siswa dengan menggunakan model pembelajaran CIRC. Berdasarkan hasil penelitian tersebutlah sehingga peneliti berinisiatif untuk mengangkat judul penelitian tentang menulis karangan narasi dengan menggunakan pembelajaran kooperatif tipe Cooperative Integrated reading and Composition(CIRC). Materi yang diangkat peneliti sebelumnya sama akan tetapi metode yang diterapkan berbeda serta subjek penelitian pun berbeda. Karena dalam penelitian ini, peneliti menggunakan metode pembelajaran kooperatif tipe Cooperative Integrated reading and Composition (CIRC) dengan subjek penelitian siswa kelas IV SD Inpres Panggentungan Selatan.

\section{TELAAH PUSTAKA}

\section{Karangan Narasi.}

Said M. Ide (2001:7) menyatakan bahwa narasi adalah wacana yang menyajikan peristiwa-peristiwa yang terjadi dalam suatu rangkaian waktu. Narasi adalah rangkaian tuturan yang menceritakan atau menyajikan suatu hal kejadian melalui tokoh atau pelaku dengan maksud memperluas pengetahuan pendengar atau pembaca (Syamsuri, A. S., \& Muhsin, M. A, 2016).

Dengan demikian dapat disimpulkan bahwa pengertian narasi adalah menyajikan jalinan peristiwa yang dapat disebut sebagai cerita dalam hubungan waktu. Penulis dapat menggunakan berbagai macam teknik bercerita, yang penting dalam narasi ialah tentang kejadian, yang disajikan tidak selalu mulai dari awal, tetapi dapat pula dimulai kisahnya dari bagian kejadian yang 
penting yang menarik perhatiannya. Contohnya:

1. Wacana narasi yang berupa fakta, misalnya otobiografi atau biografi seorang tokoh terkenal.

2. Wacana narasi yang khayali, misalnya cerpen, novel, drama, dongeng, dan lain-lain.

Selain itu, karangan narasi di bangun oleh beberapa unsur (Burhan; 2001) yakni tema, alur plot, latar, sudut pandang dan amanat.

1. Tema

Tema merupakan gagasan utama atau pikiran pokok. Tema suatu karya sastra imajinatif merupakan pikiran yang akan ditemui oleh setiap pembaca yang cermat sebagai akibat membaca karya tersebut.

2. Alur Plot

Alur adalah rangkaian pola tindak tanduk yang berusaha memulihkan situasi narasi ke dalam situasi yang seimbang

3. Latar

Latar adalah lingkungan fisik tempat kegiatan berlangsung. Latar merupakan tempat, waktu, suasana, dan keadaan sosial yang menjadi wadah tempat tokoh melakukan dan dikenai suatu peristiwa.

4. Sudut Pandang

Sudut pandang pada hakikatnya merupakan strategi, tekhnik, siasat yang secara sengaja di pilih pengarang untuk mengemukakan gagasan dan ceritanya.

5. Tokoh

Tokoh adalah perilaku yang mengembang dalam sebuah cerita fiksi sehingga cerita itu mampu menjalin sebuah cerita

\section{Pembelajaran Kooperatif}

Cooperative Learning adalah suatu strategi belajar mengajar yang menekankan pada sikap atau perilaku bersama dalam bekerja atau membantu di antara sesama dalam struktur kerjasama yang teratur dalam kelompok, yang terdiri dari dua orang atau lebih.

Pembelajaran kooperatif adalah salah satu bentuk pembelajaran yang berdasarkan faham konstruktivis. Pembelajaran kooperatif merupakan strategi belajar dengan sejumlah siswa sebagai anggota kelompok kecil yang tingkat kemampuannya berbeda. Dalam menyelesaikan tugas kelompoknya, setiap siswa anggota kelompok harus saling bekerja sama dan saling membantu untuk memahami materi pelajaran. Dalam pembelajaran kooperatif, belajar dikatakan belum selesai jika salah satu teman dalam kelompok belum menguasai bahan pelajaran.

Model pembelajaran cooperative learning adalah salah satu model pembelajaran yang menempatkan siswa sebagai subjek pembelajaran (student oriented). Dengan suasana kelas yang demokratis, yang saling membelajarkan memberi kesempatan peluang lebih besar dalam memberdayakan potensi siswa secara maksimal. Model pembelajaran cooperative learning akan dapat memberikan nunasa baru di dalam pelaksanaan pembelajaran oleh semua bidang studi atau mata pelajaran yang diampu guru. Karena pembelajaran cooperative learning dan beberapa hasil penelitian baik pakar pendidikan dalam maupun luar negeri telah memberikan dampak luas terhadap keberhasilan dalam proses pembelajaran. Dampak tersebut tidak saja kepada guru akan tetapi juga pada siswa, dan interaksi edukatif muncul dan terlihat peran dan fungsi dari guru maupun siswa.

Peran guru dalam pembelajaran cooperative learning sebagai fasilitator, moderator, organisator dan mediator terlihat jelas. Dalam kondisi ini peran dan fungsi siswa terlihat, keterlibatan semua siswa akan dapat memberikan suasana 
aktif dan pembelajaran terkesan demokratis, dan masing-masing siswa punya peran dan akan memberikan pengalaman belajarnya kepada siswa lain.

\section{Model Cooperative Integrated Reading and Composition (CIRC)}

CIRC singkatan dari Cooperative Integrated Reading and Composition, termasuk salah satu model pembelajaran cooperative learning yang pada mulanya merupakan pengajaran kooperatif terpadu membaca dan menulis (Slavin, 2008:125) yaitu sebuah program komprehensif atau luas dan lengkap untuk pengajaran membaca dan menulis untuk kelas-kelas tinggi sekolah dasar.Namun, CIRC telah berkembang bukan hanya dipakai pada pelajaran bahasa tetapi juga pelajaran eksak seperti pelajaran matematika.

Dalam model pembelajaran CIRC, peserta didik ditempatkan dalam kelompok-kelompok kecil yang heterogen, yang terdiri atas 4 atau 5 peserta didik.Dalam kelompok ini tidak dibedakan atas jenis kelamin, suku/bangsa, atau tingkat kecerdasan peserta didik. Jadi, dalam kelompok ini sebaiknya ada peserta didik yang pandai, sedang atau lemah, dan masing-masing peserta didik merasa cocok satu sama lain.

Kooperatif CIRC merupakan model pembelajaran kooperatif terpadu membaca dan menulis (Slavin, 2008:127 ) . Langkah-langkah model pembelajaran kooperatif tipe CIRC adalah sebagai berikut.
a. Membentuk kelompok yang anggotanya 4atau 5 orang yang secara heterogen
b. Guru memberikan wacana/ kliping sesuai dengan topic
c. Siswa bekerja sama saling membacakan dan menemukan ide pokok dan memberi tanggapan

terhadap wacana / kliping dan ditulis pada lembar kertas

d. Mempresentasikan hasil kerja kelompok

e. Guru membuat kesimpulan bersama

f. Penutup

CIRC juga memadukan antara membaca, menulis, dan seni berbahasa karena kita ketahui bahwa dalam membuat suatu tulisan di butuhkan wawasan yang luas. Wawasan itu datang ketika seseorang rajin membaca.

\section{METODE PENULISAN}

\section{Jenis Penelitian}

Penelitian ini termasuk Penelitian Tindakan Kelas (classroom action research). PTK merupakan suatu penelitan yang berorientasi pada usaha mencari solusi secara praktis terhadap permasalahan yang dihadapi atau memperbaiki pelaksanaan KBM. Jenis penelitian ini berdasarkan pada sifat dan karakternya, yakni (1) situasional, berkaitan dengan permasalahan kongkret yang dihadapi guru di kelas, (2) kontekstual, upaya pemecahan berupa model atau prosedur tidak terpisah dari konteksnya, baik konteks pendidikan, budaya, sosial politik, atau konteks ekonomi di mana pembelajaran berlangsung, (3) kolaboratif: partisipasi antara guru-siswa, guru-guru amat dipentingkan dalam melaksanakan PTK, (4) Self-reflective dan self- evaluatif, perilaku tindakan serta objek yang dikenai tindakan melakukan refleksi dan evalusi diri tehadap hasil. Modifikasi perubahan yang dilakukan didasarkan pada hasil refleksi dan evaluasi yang dilakukan (5) fleksibel: memberikan kelonggaran metodologis dalam melaksanakan penelitan.

\section{Fokus Penelitian}


Penelitian ini difokuskan pada peningkatan kemampuan menulis karangan narasi dengan menerapkan model pembelajaran kooperatif tipe CIRC pada murid kelas IV SD Inpres Panggentungan Selatan Kecamatan Somba Opu Kabupaten Gowa.

\section{Setting Penelitian}

Penelitian ini di laksanakan di kelas IV SD Inpres Panggentungan Selatan Kecamatan Somba Opu Kabupaten Gowa. Dengan jumlah siswa 35 orang, yang terdiri dari 18 orang laki- laki dan 17 orang perempuan. Pelaksanaan penelitian ini akan di lakukan pada semester genap tahun 2012. Berdasarkan pertimbangan masih rendahnya kemampuan siswa dalam menulis karangan,dan di sekolah tersebut belum pernah di lakukan penelitian menulis karangan narasi dengan model pembelajaran CIRC.

\section{HASIL DAN PEMBAHASAN}

\section{Hasil Penelitian}

\section{SIKLUS I}

Penalitian tindakan kelas ini telah dilaksanakan pada siswa kelas IV SD Inpres Paggentungan Selatan pada tahun ajaran 2011/2012 mulai dari bulan Februari sampai bulan April 2012. Pendekatan yang digunakan dalam penelitian ini adalah pembelajaran kooperatif tipe Cooperative Integrated reading and Composition (CIRC) dan dalam pelaksanaannya peneliti menggunakan prinsip-prinsip Penelitian Tindakan Kelas yang terdiri dari dua siklus dimana dalam setiap siklus memiliki 4 tahap, yaitu tahap perencanaan, pelaksanaan, observasi, dan refleksi.

\section{Perencanaan}

Pelaksanaan siklus I dilaksanakan sebanyak 4 kali pertemuan yang terdiri dari 3 kali proses belajar mengajar dan 1 kali evaluasi siklus.

Adapun kegiatan yang dilakukan dalam tahap perencanaan adalah sebagai berikut:

a. Menyusun rencana pelaksanaan pembelajaran (RPP).

b. Mempersiapkan semua perangkat pembelajaran yang akan digunakan dalam kelas, seperti media yang akan digunakan pada saat demonstrasi.

c. Menyusun lembar observasi untuk mengamati dan mengidentifikasi segala sesuatu yang terjadi selama proses pembelajaran berlangsung.

d. Menyusun alat evaluasi berupa tes hasil belajar siklus I.

\section{Pelaksanaan}

Adapun pelaksanaan tindakan pada siklus I ini berlangsung 4 kali pertemuan dengan lama waktu setiap pertemuan adalah $3 \times 35$ menit.

Kegiatan yang dilaksanakan dalam tahap ini adalah:

a. Melaksanakan proses pembelajaran sesuai dengan Rencana Pelaksanaan Pembelajaran yang telah dibuat pada tahap perencanaan.

b. Mengamati/mengawasi murid yang sedang melaksanakan proses pembelajaran.

c. Memberikan evaluasi kepada murid untuk mengetahui sejauh mana murid memahami meteri yang telah dipelajari pada setiap akhir pertemuan, dan memberikan tes evaluasi siklus I untuk mengetahui peningkatan hasil belajar murid.

\section{Observasi}




\section{a. Analisis Data Hasil Observasi Siklus I}

Observasi digunakan untuk mengamati keadaan, respon sikap, dan keaktifan siswa selama mengikuti proses pembelajaran menulis karangan narasi melalui pembelajaran kooperatif tipe CIRC. kegiatan observasi dilakukan selama proses pembelajaran menulis karangan deskrispi berlangsung. Adapun tabel hasil observasi siklus I sebagai berikut:

Tabel 4.1 Hasil Observasi Siswa Dalam Kelas Selama Siklus I

\begin{tabular}{|c|c|c|c|c|c|c|c|}
\hline \multirow[t]{2}{*}{ No } & \multirow[t]{2}{*}{ Komponen yang diamati } & \multicolumn{6}{|c|}{ Pertemuan ke } \\
\hline & & 1 & 2 & 3 & 4 & $\begin{array}{l}\text { Rata- } \\
\text { rata }\end{array}$ & Persentase \\
\hline 1. & $\begin{array}{l}\text { Kehadiran siswa pada saat } \\
\text { proses belajar mengajar }\end{array}$ & 29 & 31 & 33 & 35 & 32 & $91,42 \%$ \\
\hline 2. & $\begin{array}{l}\text { Siswa yang membuat catatan } \\
\text { pada saat prose belajar mengajar }\end{array}$ & 21 & 25 & 30 & $\begin{array}{l}\mathrm{T} \\
\mathrm{E}\end{array}$ & 25,33 & $72,37 \%$ \\
\hline 3. & $\begin{array}{l}\text { Siswa yang mengajukan } \\
\text { pertanyaan kepada guru pada } \\
\text { saat diskusi }\end{array}$ & 8 & 10 & 12 & $\mathrm{~S}$ & 10 & $28,57 \%$ \\
\hline 4. & $\begin{array}{l}\text { Siswa yang memberi penjelasan } \\
\text { kepada temannya pada saat } \\
\text { diskusi dalam kelompok }\end{array}$ & 13 & 6 & 5 & $\begin{array}{l}\mathrm{I} \\
\mathrm{K} \\
\mathrm{L}\end{array}$ & 8 & $22,85 \%$ \\
\hline 5. & $\begin{array}{l}\text { Siswa mendengarkan } \\
\text { penjelasan pada saat guru } \\
\text { menjelaskan materi }\end{array}$ & 18 & 23 & 29 & $\begin{array}{l}U \\
S\end{array}$ & 23,33 & $66,65 \%$ \\
\hline 6. & $\begin{array}{l}\text { Siswa yang berbicara pada saat } \\
\text { diskusi kelompok }\end{array}$ & 15 & 19 & 21 & I & 18,33 & $52,37 \%$ \\
\hline 7. & $\begin{array}{l}\text { Siswa yang melakukan kegiatan } \\
\text { lain pada saat diskusi kelompok } \\
\text { seperti main-main dan tidur }\end{array}$ & 12 & 9 & 7 & & 9,33 & $26,65 \%$ \\
\hline
\end{tabular}

Berdasarkan data observasi siklus I menunjukkan bahwa data hasil tersebut selama proses pembelajaran menulis karangan Narasi melalui pembelajaran Kooperatif tipe Cooperative Integrated reading and Composition (CIRC), sebagian besar siswa masih kurang aktif dalam mengikuti pembelajaran menulis karangan narasi.

Berdasarkan hasil data observasi tersebut dapat diketahui bahwa selama proses pembelajaran menulis karangan narasi pada siklus I masih ada beberapa siswa yang bertindak negative dan perlu adanya perbaikan untuk langkah selanjutnya, maka perlu adanya tindakan siklus II. Dengan tujuan agar memperoleh hasil yang maksimal dan tercapai target ketuntasan belajar siswa.

\section{b. Deskriptif Pelaksanaan Siklus I}

Aktifitas dalam Penelitian tindakan kelas ini adalah mengumpulkan data hasil belajar berupa data kuantitatif. Adapun hasil analisis deskriptif terhadap skor perolehan siswa setelah diterapkan pembelajaran melalui pembelajaran kooperatif tipe Cooperative Integrated reading and Composition (CIRC) pada pelajaran menulis karangan narasi maka dapat disajikan pada tabel 4.2 di bawah ini: 
Tabel 4.2 Statistik Skor Hasil Keterampilan Menulis Karangan Narasi Siswa Pada Siklus I

\begin{tabular}{lc}
\hline \multicolumn{1}{c}{ Statisitik } & Nilai Statisik \\
\hline Subjek & 35 \\
Skor ideal & 100 \\
Skor tertinggi & 85 \\
Skor terendah & 55 \\
Rentang skor & 30 \\
Skor rata-rata & 69,28 \\
\hline
\end{tabular}

Pada table 4.2 di atas dapat disimpulkan bahwa keterampilan menulis karangan narasi murid kelas IV SD Inpres Panggentungan Selatan Kecamatan Somba Opu Kabupaten Gowa pada siklus I setelah diterapkan pembelajaran kooperatif tipe Cooperative
Integrated reading and Composition $(C I R C)$, dengan jumlah sisswa sebanyak 35 orang, diperoleh skor nilai tertinggi 85 , dan skor terendah 55 dengan rentang skor 30. Dari hasil analisis data hasil menulis karangan narasi siswa pada siklus I diperoleh skor rata-rata 69,28.

Jika skor hasil belajar menulis karangan narasi siswa di atas dikelompokkan ke dalam lima kategori sesuai dengan kalsifikasi yang ditetapkan oleh Departemen Pendidikan dan Kebudayaan, maka diperoleh distribusi frekuensi dan persentase skor kemampuan siswa menulis karangan narasi setelah pelaksanaan tindakan siklus I ditunjukkan pada tabel 4.2 berikut ini:

Tabel 4.3 Distribusi Frekuensi dan Persentase Skor Hasil Keterampila Menulis Karangan Narasi Siswa Pada Siklus I

\begin{tabular}{lclcc}
\hline No & Skor & Kategori & Frekuensi & Persentase \\
\hline 1 & $0-34$ & Sangat Rendah & 0 & 0 \\
2 & $35-54$ & Rendah & 0 & 0 \\
3 & $55-64$ & Sedang & 10 & $28,57 \%$ \\
4 & $65-84$ & Tinggi & 21 & $60 \%$ \\
5 & $85-100$ & Sangat Tinggi & 4 & $11,42 \%$ \\
\hline Jumlah & & & $\mathbf{3 5}$ & \\
\hline
\end{tabular}

Tabel 4.3 menunjukkan bahwa hasil belajar Bahasa Indonesia siswa cukup bervariasi, selain itu dapat pula diketahui ketuntasan belajar siswa pada siklus I. Untuk menunjukkan ketuntasan belajar siswa skor yang dicapai harus memenuhi kriteria ketuntasan minimal yakni 68 . Jika dikaitkan dengan tabel distribusi frekuensi dan persentase skor hasil belajar Bahasa Indonesia pada siklus I maka siswa dikatakan tuntas apabila termasuk dalam kategori tinggi atau sangat tinggi.

Selanjutnya, jika ketuntasan belajar siswa didasarkan pada kriteria ketuntasan minimal $(\mathrm{KKM})$ yaitu $\geq 68$, maka frekuensi dan persentase ketuntasan hasil belajar siswa dapat dilihat pada tabel 3 berikut :

Tabel 3 : Distribusi Frekuensi dan Persentase Ketuntasan Belajar Siswa pada Pelaksanaan Tindakan Siklus I

\begin{tabular}{cccc}
\hline Ketuntasan & \multicolumn{2}{c}{ Siklus i } & Keterangan \\
\cline { 2 - 3 } & Frekuensi & Presentase $(\%)$ & \\
\hline Tuntas & 20 & 57,15 & KKM $\geq 68$ \\
\hline Tidak tuntas & 15 & 42,85 & \\
\hline
\end{tabular}




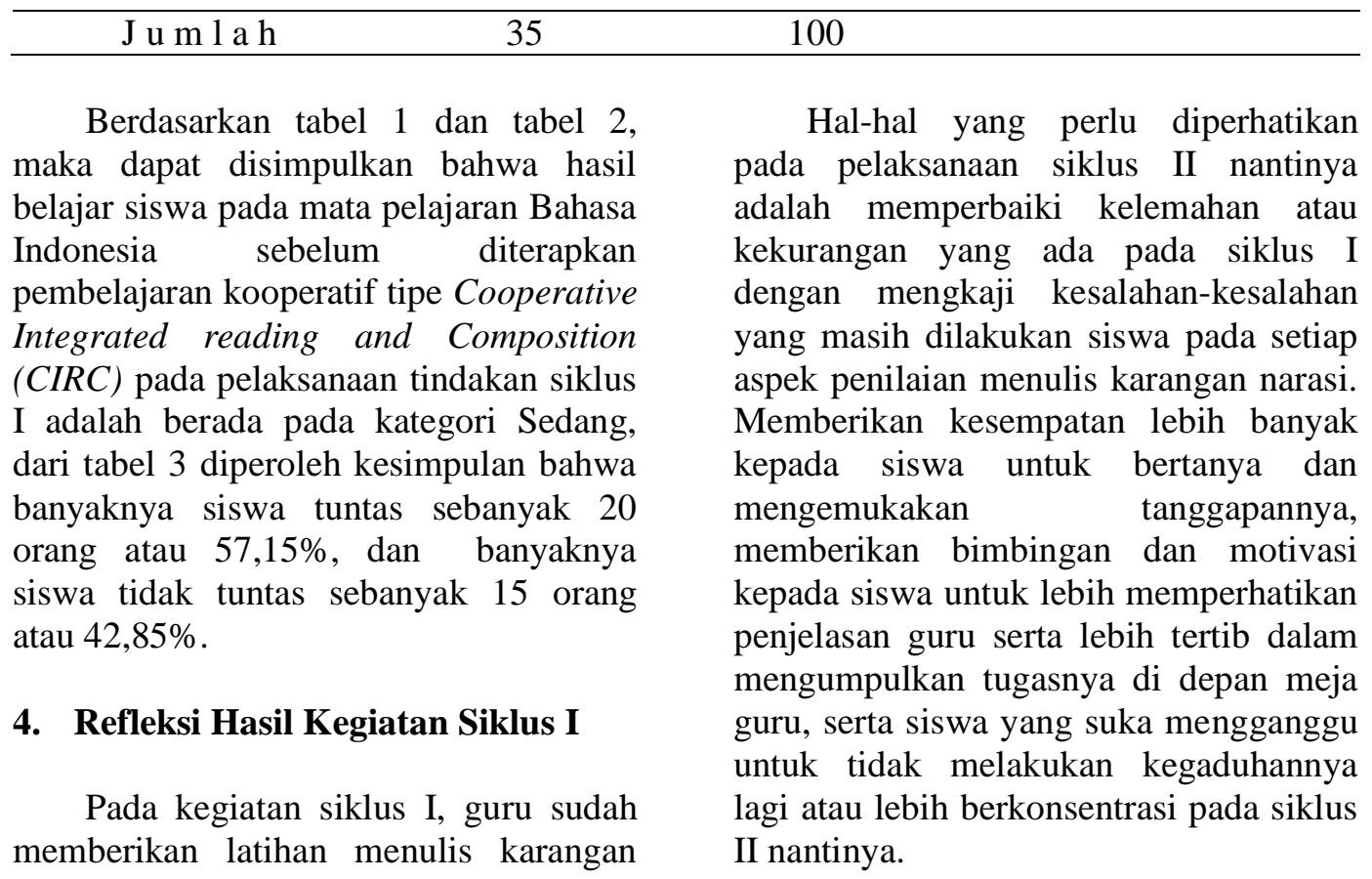
narasi kepada siswa melalui pembelajaran kooperatif tipe Cooperative Integrated reading and Composition (CIRC) pada siswa kelas IV SD Inpres Panggentungan selatan. Dari hasil tes menunjukkan bahwa hasilnya belum maksimal. Hal ini diketahui dari hasil nilai rata-rata keterampilan menulis karangan narasi siklus I sebesar 69,28\% termasuk dalam kategori sedang. Setiap aspek penilaian yang diperoleh siswa juga masih tergolong kurang. Hal itu disebabkan kurangnya pengetahuan dan pemahaman siswa terhadap materi yang diberikan oleh guru, sehingga belum mampu menulis karangan secara baik dan benar.

Berdasarkan hasil tes dan observasi pada siklus I belum mencapai target yang di tetapkan. hal tersebut perlu ditindaklanjuti dalam pembelajaran menulis karangan narasi pembelajaran kooperatif tipe Cooperative Integrated reading and Composition (CIRC) pada siklus II akan direncanakan pada pembelajaran selanjutnya dan perlu persiapan dan perencanaan yang matang lagi.

\section{SIKLUS II}

\section{Perencanaan}

Tahap perencanaan pada siklus II dilakasanakan dengan pertimbangan bahwa pelaksanaan pada siklus I belum sepenuhnya berhasil mencapai kriteria ketuntasan minimum (KKM) nilai 68. Tahap perencanaan Siklus II memperhatikan beberapa hal dengan mempelajari kembali Kurikulum Tingkat Satuan Pendidikan (KTSP) 2006 untuk kelas IV Sekolah Dasar

Selanjutnya, membuat kembali Rencana Pelaksanaan Pembelajaran (RPP), lembar observasi untuk melihat aktivitas belajar murid pada saat proses pembelajaran berlangsung melalui pembelajaran kooperatif tipe Cooperative Integrated reading and Composition (CIRC).

\section{Pelaksanaan}

Pada tahap pendahuluan, guru menyampaikan tujuan pembelajaran, 
manfaat pembelajaran, memotivasi murid dan menampilkan media yang digunakan pada proses pembelajaran.

Kegiatan yang dilaksanakan dalam tahap ini adalah:

a. Melaksanakan proses pembelajaran sesuai dengan RPP yang telah dibuat.

b. Mengawasi murid yang mengikuti proses pembelajaran.

c. Memberikan evaluasi pada akhir pertemuan kepada murid untuk mengetahui sejauh mana murid memahami materi yang telah dipelajari, dan memberikan tes evaluasi pada akhir pelaksanaan siklus II untuk mengetahui peningkatan keterampilan menulis karangan narasi

\section{Observasi}

\section{a. Analisis data hasil observasi siklus II}

Observasi digunakan untuk mengamati keadaan, respon sikap, dan keaktifan siswa selama mengikuti proses pembelajaran menulis karangan narasi melalui pembelajaran kooperatif tipe Cooperative Integrated reading and Composition (CIRC). kegiatan observasi dilakukan selama proses pembelajaran menulis karangan narasi berlangsung

Pada proses observasi siklus II tampak bermacam-macam perilaku siswa baik yang positif maupun tingkah laku yang negatif. Hasil observasi selama pembelajaran menulis karangan narasi melalui pembelajaran kooperatif tipe CIRC dapat dilahat pada table berikut ini

Tabel 4.4 Hasil Observasi Siswa Dalam Kelas Selama Siklus II

\begin{tabular}{|c|c|c|c|c|c|c|c|}
\hline \multirow[t]{2}{*}{ No } & \multirow[t]{2}{*}{ Komponen yang diamati } & \multicolumn{6}{|c|}{ Pertemuan ke } \\
\hline & & 1 & 2 & 3 & 4 & $\begin{array}{l}\text { Rata- } \\
\text { rata }\end{array}$ & Persentase \\
\hline 1. & $\begin{array}{l}\text { Kehadiran siswa pada saat proses } \\
\text { belajar mengajar }\end{array}$ & 32 & 33 & 35 & 35 & 33,75 & $96,42 \%$ \\
\hline 2. & $\begin{array}{l}\text { Siswa yang membuat catatan } \\
\text { pada saat prose belajar mengajar }\end{array}$ & 30 & 31 & 35 & $\begin{array}{l}\mathrm{T} \\
\mathrm{E}\end{array}$ & 32 & $91,42 \%$ \\
\hline 3. & $\begin{array}{l}\text { Siswa yang mengajukan } \\
\text { pertanyaan kepada guru pada } \\
\text { saat diskusi }\end{array}$ & 10 & 7 & - & $\mathrm{S}$ & 5,67 & $16,2 \%$ \\
\hline 4. & $\begin{array}{l}\text { Siswa yang memberi penjelasan } \\
\text { kepada temannya pada saat } \\
\text { diskusi dalam kelompok }\end{array}$ & 13 & 17 & 26 & $\begin{array}{l}\mathrm{I} \\
\mathrm{K} \\
\mathrm{L}\end{array}$ & 18,67 & $53,34 \%$ \\
\hline 5. & $\begin{array}{l}\text { Siswa mendengarkan } \\
\text { penjelasan pada saat guru } \\
\text { menjelaskan materi }\end{array}$ & 25 & 32 & 35 & $\begin{array}{l}\mathrm{U} \\
\mathrm{S}\end{array}$ & 30,67 & $87,62 \%$ \\
\hline 6. & $\begin{array}{l}\text { Siswa yang berbicara pada saat } \\
\text { diskusi kelompok }\end{array}$ & 8 & 4 & - & II & 3,9 & $11,14 \%$ \\
\hline 7. & $\begin{array}{l}\text { Siswa yang melakukan kegiatan } \\
\text { lain pada saat diskusi kelompok } \\
\text { seperti main-main dan tidur }\end{array}$ & 7 & 3 & 2 & & 4 & $11,42 \%$ \\
\hline
\end{tabular}

Berdasarkan data observasi siklus II manunjukkan bahwa data hasil tersebut selama proses pembelajaran menulis karangan narasi melalui pembelajaran 
kooperatif tipe Cooperative Integrated reading and Composition (CIRC) sebagian besar siswa sudah lebih baik daripada siklus I dalam mengikuti pembelajaran menulis karangan narasi.

Pada siklus II ini, siswa sudah lebih baik dalam mengikuti proses pembelajaran menulis karangan narasi melalui pembelajaran kooperatif tipe Cooperative Integrated reading and Composition (CIRC).berdasarkan hasil data Observasi tersebut dapat diketahui bahwa selama proses pembelajaran menulis karangan narasi melalui pembelajaran kooperatif tipe Cooperative Integrated reading and Composition $(C I R C)$. pada siklus II sudah mengalami peningkatan yang lebih baik daripada siklus I. walaupun masih ada beberapa siswa yang bertindak negatif. Dengan demikian, hasil data observasi pada siklus II sudah mengalami hasil yang maksimal.

\section{b. Deskriptif pelaksanaan siklus II}

Aktifitas dalam Penelitian tindakan kelas ini adalah mengumpulkan data hasil belajar berupa data kuantitatif. Adapun hasil analisis deskriptif terhadap skor perolehan siswa setelah diterapkan pembelajaran melalui pembelajaran kooperatif tipe Cooperative Integrated reading and Composition (CIRC). pada pembelajaran menulis karangan narasi maka dapat disajikan pada tabel $4.5 \mathrm{di}$ bawah ini:

Tabel 4.5 Statistik Skor Hasil

Keterampilan Menulis

Karangan Narasi Siswa Pada Siklus II

\begin{tabular}{lc}
\hline Statisitik & Nilai Statisik \\
\hline Subjek & 35 \\
Skor ideal & 100 \\
Skor tertinggi & 95 \\
Skor terendah & 70 \\
Rentang skor & 25 \\
Skor rata-rata & 76,71
\end{tabular}

Dari tabel 4.5 di atas menunjukkan bahwa skor rata-rata hasil belajar siswa menulis karangan narasi melalui pembelajaran kooperatif tipe CIRC SD Inpres Panggentungan Selatan setelah pelaksanaan tindakan siklus II adalah 76,71 dari skor maksimum ideal yang mungkin dicapai adalah 100 dengan skor tertinggi 95 sedangkan skor terendah yang dicapai adalah 70

Jika skor hasil belajar siswa menulis karangan narasi dikelompokkan ke dalam lima kategori maka diperoleh distribusi frekuensi dan persentase skor hasil belajar siswa menulis karangan narasi melalui pembelajaran kooperatif tipe Cooperative Integrated reading and Composition (CIRC) pada siklus II seperti yang ditunjukkan pada tabel 4.5 berikut ini:

Tabel 4.6 Distribusi Frekuensi dan Persentase Skor Hasil Keterampilan Menulis Karangan Narasi Siswa Pada Siklus II

\begin{tabular}{lclcc}
\hline No & Skor & Kategori & Frekuensi & Persentase \\
\hline 1 & $0-34$ & Sangat Rendah & 0 & 0 \\
2 & $35-54$ & Rendah & 0 & 0 \\
3 & $55-64$ & Sedang & 0 & 0 \\
4 & $65-84$ & Tinggi & 31 & $88,57 \%$ \\
5 & $85-100$ & Sangat Tinggi & 4 & $11,43 \%$ \\
\hline & Jumlah & & $\mathbf{3 5}$ & $\mathbf{1 0 0 \%}$
\end{tabular}


Pada tabel 4.6 di atas tampak bahwa dari 35 siswa kelas IV SD Inpres Panggentungan Selatan yang menjadi sampel penelitian terdapat 31 siswa atau $88,57 \%$ berada pada kategori tinggi dan 4 siswa atau $11,43 \%$ siswa berada pada kategori sangat tinggi.

Jika skor rata-rata kemampuan siswa yang diperoleh pelaksanaan tindakan siklus II yaitu 76,71 dikonversikan ke dalam pengkategorian hasil belajar yang ditetapkan oleh Departemen Pendidikan dan Kebudayaan, maka skor rata-rata kemampuan siswa menulis karangan narasi tergolong tinggi.

Narasi secara kuantitatif ketuntasan belajar siswa menulis karangan setelah pemberian tindakan siklus II, ditunjukkan pada tabel 4.6 berkut ini:

\section{Tabel 4.6 Distribusi Nilai Ketuntasan Hasil Keterampilan Menulis}

Karangan Narasi Siswa Pada Siklus II

\begin{tabular}{clcc}
\hline Skor & Kategori & Frekuensi & Persentase (\%) \\
\hline $0-64$ & Tidak Tuntas & 0 & 0 \\
\hline $65-100$ & Tuntas & 35 & $100 \%$ \\
\hline & Jumlah & $\mathbf{3 5}$ & $\mathbf{1 0 0 \%}$
\end{tabular}

Dari tabel 4.6 di atas 23 siswa atau sebesar $100 \%$ hasil belajarnya dikatakan tuntas atau mendapat skor $64 \mathrm{ke}$ atas. Jadi ketuntasan belajar siswa kelas IV SD Inpres panggentungan Selatan dalam pelaksanaan tindakan siklus II melalui pembelajaran kooperatif tipe Cooperative Integrated reading and Composition (CIRC) telah tercapai. Hal ini berarti pembelajaran menulis karangan narasi melalui pembelajaran kooperatif tipe Cooperative Integrated reading and Composition (CIRC) mengalami peningkatan.

Selanjutnya pada tabel 4.7 akan kita lihat peningkatan kemampuan siswa setelah pelaksanaan tindakan melalui pembelajaran kooperatif tipe Cooperative Integrated reading and Composition (CIRC) dalam proses belajar mengajar pada siklus I dan siklus II

Tabel 4.7 Distribusi frekuensi dan persentase skor setelah proses pembelajaran pada siklus I dan II.

\begin{tabular}{lllcccc}
\hline No & Skor \% & \multirow{2}{*}{ Kategori } & \multicolumn{2}{c}{ Frekuensi } & \multicolumn{2}{c}{ Persentase } \\
\cline { 4 - 7 } & & & Siklus I & Siklus II & Siklus I & Siklus II \\
\hline 1 & $0-34$ & Sangat rendah & 0 & 0 & 0 & 0 \\
2 & $35-54$ & Rendah & 4 & 0 & $11,43 \%$ & 0 \\
3 & $55-64$ & Sedang & 11 & 0 & $31,43 \%$ & 0 \\
4 & $65-84$ & Tinggi & 20 & 31 & $57,14 \%$ & $88,57 \%$ \\
5 & $85-100$ & Sangat Tinggi & 0 & 4 & 0 & $11,43 \%$ \\
\hline
\end{tabular}

Dengan memperhatikan tabel $4.7 \mathrm{di}$ atas, terdapat hasil yang menampakkan peningkatan hasil menulis karangan narasi siswa setelah dua kali dilaksanakan tes dalam tiap siklus, dimana pada siklus I terdapat 4 siswa atau $11,43 \%$ yang berada pada kategori rendah dan pada siklus II mengalami penurunan menjadi 0 siswa atau $0 \%$ yang berada pada kategori sedang, kemudian pada siklus I terdapat 11 siswa atau $31,43 \%$ yang berada pada kategori 
sedang dan pada siklus II mengalami penurunan menjadi 0 siswa atau $0 \% .20$ siswa atau $57,14 \%$ yang berada pada kategori tinggi, menimgkat menjadi 31 siswa atau $88,57 \%$. selanjutnya untuk kategori sangat tinggi pada siklus I tidak ada siswa yang termasuk kategori tersebut kemudian pada siklus II mengalami peningkatan menjadi 4 siswa atau $11,43 \%$ yang berada pada kategori sangat tinggi.

\section{Refleksi Hasil Kegiatan Siklus II}

Pada siklus II nampak keaktifan siswa dalam menyusun karangan narasi meningkat, jika sebelumnya masih banyak siswa yang belum mampu menulis karangan sesuai dengan apa yang diharapkan, maka pada siklus II siswa sudah mampu menulis karangan narasi dengan memperhatikan pengembangan ide (gagasan), kesesuaian judul, penggunaan ejaan dan tanda baca, keefektifan kalimat dan kelengkapan isi.

\section{B. Pembahasan hasil penelitan}

Keterampilan menulis karangan narasi pada siswa kelas IV SD Inpres Panggentungan Selatan tahun 2012 dapat meningkat dengan diterapkannya pembelajaran kooperatif tipe Cooperative Integrated reading and Composition (CIRC). Peningkatan tersebut bukan hanya pada nilai akhir menulis krangan narasinya saja, tetapi pada proses pembelajaran menulisnya juga. Keaktivan siswa dalam mengikuti pembelajaran meningkat dari siklus I sampai siklus II. Hal ini dapat dilahat dari hasil pengamatan terhadap aktivitas siswa dalam proses pembelajaran. Selain keaktifan, terlihat pula terjadi peningkatan pada aspek keberanian, kreativitas dan inisiatif siswa. Peningkatan hasil menulis karanga narasi dapat dilihat pada tabel di bawah ini.
Tabel Statistik Perbandingan Skor Rata-rata Pada Siklus I dan Siklus II

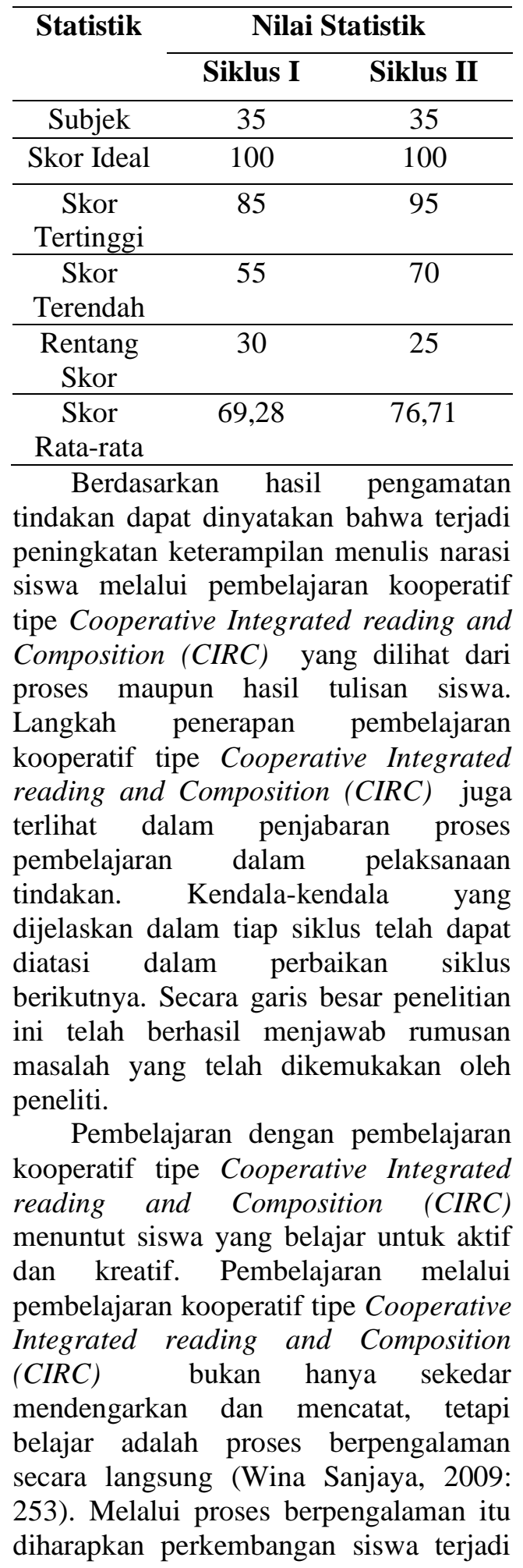


secara utuh, yang tidak hanya berkembang dalam aspek kognitif saja, tetapi juga aspek afektif dan psikomotorik.

\section{KESIMPULAN}

Berdasarkan rumusan masalah, hasil analisis data dan pembahasan, sebagaimana yang telah diuraikan maka dapat ditarik kesimpulan sebagai berikut hasil analisis deskriptif menunjukkan bahwa skor rata-rata hasil belajar bahasa Indonesia siswa kelas IV SD I npres Panggentungan Selatan Kecamatan Somba Opu Kabupaten Gowa yang mengikuti pembelajaran kooperatif tipe CIRC pada siklus I adalah 69,28 dari skor ideal 100 dan berada pada kategori sedang. Sedangkan pada siklus II skor rata-rata meningkat menjadi 76,71 dari skor ideal 100 dan berada pada kategori tinggi. Dengan demikian, terjadi peningkatan hasil belajar bahasa Indonesia siswa kelas IV SD Inpres Panggentungan Selatan Kecamatan Somba Opu Kabupaten Gowa dengan menggunakan model pembelajaran kooperatif tipe CIRC.

\section{DAFTAR PUSTAKA}

Akhadiah, Sabarti. 1996. Menulis . Jakarta: Karunia Universitas Terbuka.

-------. 1998. Menulis II. Jakarta: Karunia Universitas Terbuka.

Ambo Enre, Fachruddin . 1994. Dasardasar Keterampilan Menulis. Ujung Pandang: IKIP Ujung pandang.

Basri.2005.Kemampuan Siswa Kelas II SMA Negeri I Majene Menulis Karangan Persuasi. Skripsi (tidak diterbitkan).Makassar: $\quad$ FBS Universitas Negeri Makassar.

Brotowidjoyo, Mukayat D., 2002.Penulisan Karangan Ilmiah
Edisi Revisi. Jakarta: Akademika Pressindo

Depdikbud.1997. Kamus Besar Bahasa Indonesia. Jakarta: Balai Pustaka

Depdiknas 2006.Standar Isi. Jakarta:

Badan Standar Nasional

Pendidikan (BSNP).

Ibrahim, Muslimin. Dkk. 2002.Pembelajaran Kooperatif. Surabaya: University Press.

Isjoni. 2009. Cooperative Learning. Bandung: Alfabeta

Komariah, Titik . Belajar Mengarang .Semarang:Aneka Ilmu.

Kosasih, E. 2002.Kompetensi

Ketatabahasaan: Cermat

Berbahasa Indonesia. Bandung:

Yrama Widya.

Muda, Ahmad. 2006.Kamus Lengkap

Bahasa Indonesia.Jakarta:Reality Publisher.

Muslich Masnur.2010.Penelitian Tindakan Kelas itu Mudah. Jakarta: Bumi Aksara

Nuralim. 2011. Upaya Peningkatan Keterampilan Membaca Bahasa Indonesia Melalui Penerapan Model pembelajaran CIRC pada Siswa Kelas V SDN 240 Walemping Kabupaten Soppeng. Skripsi. Makassar: Universitas Muhammadiyah Makassar.

Nurgiyantoro, Burhan. 2001. Penilaian dalam Pengajaran Bahasa dan Sastra Yogyakarta: BPFE-Yogyakarta.

Nurhadi. Dkk.2003. Pembelajaran Kooperatif dan Penerapannya dalam KBK. Malang: Universitas Negeri Malang.

Rafi'uddin. 1996. Rancangan Penelitian Tindakan. Lokakarya Tingkat Lanjut Penelitian Kualitatif Angkatan V Tahun 1996/1997. Malang: IKIP Malang

Sawi, Nurhayati. 2009. Pemanfaatan Strategi Neighboardhood Walk, 
Pengamatan Terhadap

Lingkungan Sekitar' dalam

Pembelajaran Menulis Narasi

Siswa Kleas X6 SMA Negeri 1

Takalar. Skripsi. Universitas

Negeri Makassar

Said D.M., M. Ide. 2001. Teori Linguistik.Makassar: Universitas Negeri Makassar.

Slavin, Robert E. 2008. Cooperative

Learning. Teori, Riset, dan

Praktik. Bandung: Nusa Media.

Soedjito dan Hassan, M. 1986.Seri

Membina Keterampilan Menulis

Paragraf. Malang: IKIP Malang.

Sugiyono.2007. Metode Penelitian

Pendidikan Pendekatan

Kuantitatif, Kualitataif, dan $R \& D$.

Bandung: Alfabeta.

Suparno dan yunus, M. 2002.

Keterampilan Dasar Menulis.

Jakarta: UniversitasTerbuka

Syafi'ie, Imam. 1988. Retorika dalam

Menulis. Jakarta: Depdikbud.

Syamsuri, A. S., \& Muhsin, M. A.

(2016). The Effectiveness of

Caricature Media in Learning

Writing of Argumentation

Paragraph. Theory and Practice in

Language Studies, 6(11), 2079.

Tarigan, Henry Guntur. 1986. Menulis

Sebagai Suatu Keterampilan

Berbahasa. Bandung: Penerbit

Angkasa

1996. Teknik

Pengajaran Keterampilan

Berbahasa. Bandung: Rineka

Cipta

Widyamartaya, A. 1996. Kreatif

Mengarang. Yogyakarta: Kanisius 